\title{
DOUTRINA
}

\section{TETO CONSTITUCIONAL DE REMUNERAÇÃO DOS AGENTES PÚBLICOS:}

Uma crônica de mutações e emendas constitucionais ${ }^{\prime}$

PAULO MODESTO ${ }^{2}$

1. Impropriedade da expressão teto de remuneração. 2. Fixação de limites máximos de remuneração na redação original da constituição de 1988. 3. Fixação de limites máximos de retribuição na emenda constitucional $n^{\circ} 19$, de 4 de junho de 1998. 4. Parcelas excluídas dos limites máximos no novo regime constitucional. 5. Previsão de limites inferiores ao teto constitucional nacional (subteto). 6. Diferenças e semelhanças entre 0 novo sistema e o previsto originalmente pela Constituição de 1988. 7. A posição do Supremo Tribunal Federal sobre a eficácia das novas disposições constitucionais sobre teto de retribuição; 8 . Impasse na definição do teto constitucional. 9. Impropriedade da fixação de tetos constitucionais estaduais. 10. Alteração do novo teto constitucional.

1 Texto base da exposição realizada no XXVI Encontro Nacional de Procuradores Municipais, realizado em Vitória, Estado do Espírito Santo, em 3 de agosto de 2000. O texto sintetiza considerações e apontamentos que vimos fazendo sobre o tema desde 1998, em diversos congressos e seminários, mas sem registro formal, salvo alguns trechos divulgados em documentos apresentados durante a discussão da Reforma Administrativa do Senado Federal. Contempla, ainda, observaçōes inéditas sobre a Proposta de Emenda Constitucional 137-A, de 1999, Relatada pelo Deputado Vicente Arruda, recentemente aprovada na Comissão Especial da Câmara dos Deputados e breve referência à Emenda Constitucional $n^{\circ} 25$, de 14 de fevereiro de 2000.

2 Professor de Direito Administrativo da Universidade Federal da Bahia (UFBA) e Universidade Salvador (UNIFACS). Coordenador do Curso de Especialização em Direito Público da UNIFACS. Membro do Ministério Público da Bahia, do Instituto Brasileiro de Direito Administrativo e do Instituto dos Advogados da Bahia. Conselheiro Técnico da Sociedade Brasileira de Direito Público (SBDP). Ex-Assessor Especial do Ministério da Administração Federal e Reforma do Estado. E-mail:paulomodesto/yahoo.com 


\section{Impropriedade da expressão teto de remuneração}

A Constituição Federal de 1988, em sua redação original, não empregava a expressão "teto de remuneração". Mas contemplava um sistema de estabelecimento de limites à retribuição dos agentes públicos freqüentemente associado à fórmula "teto de remuneração". Esta expressão nunca foi precisa ou fiel à complexidade do sistema constitucional na matéria, mas nesse momento parece ainda mais equívoca e imprópria. Com a promulgação da Emenda Constitucional nº 19 (Reforma Administrativa), o sistema constitucional passou a cuidar de duas espécies distintas de retribuição pelo exercício de cargo, emprego, função ou mandato público: "remuneração" e "subsídio". A distinção clara entre essas duas formas de retribuição, explícita no novo sistema, obrigaria no tratamento da matéria ao emprego da expressão "teto de retribuição", "limites constitucionais à retribuição" e não a simples utilização da expressão tradicional "teto de remuneração". Mas quem escrever deste modo novo, sem maiores advertências, corre o risco de não ser entendido. Por isso, a locução "teto de remuneração", mais conhecida e ainda usual, continuará a ser empregada neste trabalho com as ressalvas referidas.

\section{Fixação de limites máximos de remuneração na redação original da Constituição de 1988}

A fixação de limites máximos de remuneração para os agentes públicos recebeu do constituinte de 1988 uma atenção especial. São diversos os dispositivos dedicados ao assunto. $O$ preceito central na matéria, contemplado no art. 37 , XI, vinha assim expresso:

“Art. 37

“XI - a lei fixará o limite máximo e a relação de valores entre a maior e a menor remuneração dos servidores públicos, observados, como limites máximos e no âmbito dos respectivos Poderes, os valores percebidos como remuneração, em espécie, a qualquer título, por membros do Congresso Nacional, Ministros de Estado e Ministros do Supremo Tribunal Federal e seus correspondentes nos Estados, no Distrito Federal e nos Territórios, e, nos Municípios, os valores percebidos como remuneração, em espécie, pelo Prefeito"

A redação original do inciso XI do art. 37 da Constituição Federal sugeria um comando inflexível ("remuneração, em espécie, a qualquer título"), com abertura apenas para maiores restrições em termos do valor limite admitido ("a lei fixará o limite máximo e a relação de valores entre a maior e a menor remuneração"). A rigidez do texto original do art. 37, XI, da Constituição Federal era fortalecida pelo art. 17 do ADCT, ainda vigente, que impunha a aplicação dos limites decorrentes da Constituição aos servidores ativos e inativos e recusava, havendo excesso, a invocação de direito adquirido ou de imunidade a qualquer outro título. 
O enunciado do Art. 17 do Ato das Disposições Constitucionais Transitórias merece ser referido:

“Os vencimentos, a remuneração, as vantagens e os adicionais, bem como os proventos de aposentadoria que estejam sendo percebidos em desacordo com a Constituição, serão imediatamente reduzidos aos limites dela decorrentes, não se admitindo, neste caso, invocação de direito adquirido ou percepção de excesso a qualquer título".

O texto original do art. $37, \mathrm{XI}$, da Constituição Federal de 1988 contemplava a referência a dois tipos de limites máximos de remuneração: um limite que foi delegado à lei ordinária estabelecer e um limite imposto desde logo à lei pelo estatuto constitucional.

A todo rigor, a lei ordinária poderia fixar um "limite máximo" de remuneração igual $^{3}$ ou inferior ${ }^{4}$ à remuneração dos paradigmas apontados na Constituição: na União, os Ministros de Estado, Ministros do Supremo Tribunal Federal e Congressistas; nos Estados, os agentes correspondentes (Secretários de Estado, Desembargadores e Deputados Estaduais); nos Municípios, o Prefeito. Quando a lei ordinária fixava o limite máximo de remuneração em valor abaixo do pago aos agentes referidos pela Constituição Federal como paradigmas finais ou teto, dizia-se a lei fixava um redutor ou subteto.

Como a Constituição Federal não especifica a quem caberia a iniciativa dessa lei, entendeu-se que ela competia a quem detinha a iniciativa de lei ou competência para edição de ato normativo com eficácia equivalente para fixação da remuneração dos servidores em geral: na União, o Presidente da República para os servidores do Executivo (art. 61, § $1^{\circ}$, II, "a"), a Câmara e o Senado Federal para os servidores do Legislativo (arts. 51, IV e 52, XIII), o Supremo Tribunal Federal e os Tribunais Superiores para os servidores do Judiciário (art. 96, II, "b"); o Procurador Geral da República, para os servidores do Ministério Público Federal (art. 127, § $2^{\circ}$ ); nos Estados, respectivamente, os Governadores, as Assembléias Legislativas, os Tribunais de Justiça, os Procuradores Gerais de Justiça; nos Municípios, os Prefeitos e as Câmaras Municipais.

Na União Federal, apenas o Poder Executivo tomou a iniciativa de assegurar a definição de um subteto para os vencimentos dos servidores. $O$ primeiro redutor (10\%) foi estabelecido pela Lei 8.852, de 04/02/1994 (art. $2^{\circ}$ ) e foi posteriormente ampliado $(20 \%)$, mediante sucessivas medidas provisórias, até a conversão da Medida Provisória 1480-40 na Lei 9.624, de 8/04/1998 (art. 10) ${ }^{5}$ Os demais Poderes

3 CF. Na União Federal, Lei $n^{\circ} 8.112 / 90$, Art. 42.

4 Cf. Na União Federal, Art. $2^{\circ}$ da Lei 8.852, de 04/02/1994, e Art. 10 da Lei 9.624, de 8/04/1998. Cf., também, art. $3^{\circ}$ e $5^{\circ}$ da Lei 8.448 , de $21 / 07 / 1992$

5 Prescreve o referido art. 10 da Lei 9.624 , em vigor: "Art. 10 . O maior valor de vencimentos a que se refere $o$ art. $2^{\circ}$ da Lei $n^{\circ} 8.852$, de 4 de fevereiro de 1994, passa a corresponder a, no máximo, oitenta por cento da remuneração devida o Ministro de Estado". 
não apresentaram projeto de lei com vistas à definição de limite máximo de remuneração abaixo do patamar constitucional permitido. ${ }^{6}$

O legislador ordinário, no entanto, estava autorizado pela Constituição Federal a estabelecer não apenas um limite fixo, definido a partir da determinação de um valor nominal certo ou definido mediante a aplicação de percentual determinado sobre a remuneração de um dos limites constitucionais máximos. Na verdade, repita-se, o legislador ordinário recebia da Constituição duas "tarefas"; "fixar os limites máximos" e "estabelecer a relação entre a maior e a menor remuneração". A primeira competência permitia a fixação do que venho chamando de subteto fixo. ${ }^{7}$ A Segunda competência, diversamente, dizia respeito à fixação de uma escala móvel de limites, de um limite móvel de remuneração (ou subteto móvel), pois apenas poderia consistir numa equação da relação entre a menor e da maior remuneração para fins de defínição de limites abaixo do limite constitucional máximo de remuneração. ${ }^{8} \mathrm{O}$ sistema apresentava efetivamente, uma flexibilidade elogiável ${ }^{9}$

6 A Lei $n^{\circ} 8.448$, de 21/07/1992, conhecida também como Lei da Isonomia, poderia sugerir entendimento diverso, pois previa em seu art. $3^{\circ}$, de forma expressa, limite de remuneração para todos os servidores civis de administração pública direta, autárquica e fundacional dos Poderes da União e aplicável também ao pessoal militar. No entanto, não produziu qualquer efeito prático, pois contemplava paradoxalmente norma que resguardava os servidores que ultrapassassem os limites estabelecidos de qualquer redução de remuneração. Com efeito, no seu art. $5^{\circ}$, enunciava: "Art. $5^{\circ}$ A parcela de remuneração que, na data da promulgação desta lei, exceder o limite fixado no inciso II do art. $3^{\circ}$, será mantida como diferença individual, em valor fixo e irreajustável." É discutível a constitucionalidade dessa ressalva da lei ante os termos abrangentes do art. 17 do Ato das Disposições Constitucionais Transitórias. É discutível também a constitucionalidade da fixação de subteto para os servidores do Poder Legislativo, do Poder Judiciário e do Ministério Público por lei de iniciativa do Presidente da República, diante do princípio da separação dos Poderes e das competências privativas previstas nos artigos 51, IV; 52, XIII; 96, II, b; 127 , $2^{\circ}$.

7 Essa modalidade foi a mais utilizada durante toda a vigência do texto original do art. 37, XI, da Constituição, conhecendo diversas aplicaçōes também nos Estados e Municípios, sendo muitas vezes confundida com o próprio conceito de subteto, de que era apenas espécie. $\mathrm{Na}$ Uniāo, como referido, foi adotada pela Lei 8.852, de 04/02/1994 (art. $2^{\circ}$ ) e pela Lei 9.624 , de 8/04/1998 (art. 10).

8 Essa via foi adotada pela Lei 8.448 , de $21 / 07 / 1992$, art. $3^{\circ}$, verbis: : Art. $3^{\circ}$ A relação de valores entre a maior $e$ a menor remuneração dos servidores públicos referidos no artigo anterior é fixada da forma seguinte: I - o valor do maior vencimento básico ou soldo não poderá ser superior a vinte vezes o menor vencimento básico ou soldo; II - a soma das vantagens percebidas pelo servidor não poderá exceder a duas vezes o valor do maior vencimento básico ou soldo permitido como teto dos termos do inciso anterior, excluídos: a) salário-família; b) diárias; c) ajuda-de-custo em razão de mudança de sede: d) indenização de transporte; e) adicional ou gratificação de tempo de serviço; f) gratificação ou adicional natalinos; g) abono pecuniário; auxílio ou adicional de natalidade e de funeral; $h$ ) adicional de férias; $i)$ auxílio-fardamento; $j$ ) adicional pela prestação de serviço extraordinário; 1 ) adicional noturno; $m$ ) gratificação de compensação orgânica; $n$ ) gratificação de habilitação militar; o) gratificação prevista no art. 62 da Lei $n^{\circ} 8.112$, de 11 de dezembro de 1990; p) vantagens incorporáveis das parcelas de quintos". Vale observar, ainda, a utilização que a Lei 8.112/90 fez dessa abertura dada pela lei fundamental: sem fixar um subteto fixo ou móvel, vale dizer, um valor de remuneração inferior ao máximo admitido, a lei instituiu um piso de remuneração relacionado ao teto máximo, prescrevendo que "a menor remuneração atribuída 
Nada disso impediu, no entanto, o completo descrédito da norma constitucional referente aos limites gerais de remuneração. Poucos meses após a promulgação do texto constitucional de 1988, o Supremo Tribunal Federal decidiu que os limites de remuneração, fixados de modo a impedir a percepção de excessos "a qualquer título", admitiam exceções e atenuações relevantes. $O$ acórdão inaugural dessa orientação foi proferido na ADIn 14, Relatada pelo Ministro CÉLIO BORJA (STF, DJ data 01/12/89, pp-17.759, julgamento 28/09/1989 - Tribunal Pleno, votação unânime, RTJ 130/475, de 1989). Nesta decisão, assentou o Supremo Tribunal várias conclusões importantes, que podem ser resumidas no seguinte:

a) a conjugação do art. $37, \mathrm{XI}$ com o art. $39, \S 1^{\circ}$, da Constituição Federal importa na exclusão das vantagens individuais (também chamadas "vantagens pessoais") e das vantagens relativas à natureza e local de trabalho dos limites máximos de remuneração;

b) os paradigmas máximos, pela mesma conjugação, devem guardar vencimentos equivalentes (princípio da equivalência).

A jurisprudência subsequiente corroborou esse entendimento, com detalhamentos adicionais:

a) a norma do art. 37, XI, é auto-aplicável, no plano federal, estadual e municipal e no Distrito Federal, porque dotada de suficiente densidade normativa, independentemente da promulgação da lei a que seu texto alude (STF, ADIMC-

aos cargos de carreira não será inferior a $1 / 40$ (um quarenta avos) do teto de remuneração fixado no artigo anterior" (art. 43).

9 Tratava-se de sistema flexível, marcado pela consideração do princípio da separação dos Poderes e pelo princípio federativo, pois entregava ao legislador ordinário, mediante iniciativas específicas, a definição de "limites máximos" e da "relação entre a maior e a menor remuneração" dos agentes públicos, sem embargo da definição de limites rígidos de matriz constitucional distintos entre os Poderes e entre as unidades da Federação. Essa flexibilidade explica porque, disciplinando as situações em curso, entendeu o constituinte de fixar no art. 17 do Ato das Disposições Transitórias que os "limites decorrentes da Constituição" (e não apenas os nela previstos) estariam imunes à incidência da garantia do direito adquirido, recusando a percepção de excesso “a qualquer título". Trata-se da única exceção aberta pelo constituinte originário à tutela de direito adquiridos contra a incidência imediata de norma gravosa aprovada pelo legislativo ordinário. Sem ela, a delegação feita ao legislador ordinário para fixar "limites máximos" seria inócua. Sobre a questão, conferir artigo que escrevi sob o título. "Reforma Administrativa e Direito Adquirido", publicado Revista Trimestral de Direito Público (RTDP), n. 18, 1997, p. 165-178; Revista de Direito Administrativo (RDA); Vol. 211, jan/mar, 1998; Revista de Direito Administrativo \& Constitucional, Curitiba, Ed. Juruá, $\mathrm{n}^{\circ} 1$, ano 1,1999 , pp. 23-48. A flexibilidade legislativa, porém, além dessa maior insegurança jurídica, contemplava outros aspectos negativos; deixava sem "limite constitucional" os Prefeitos Municipais, os Deputados e Senadores da República, os Ministros de Estado, os Secretários de Estado e os Ministros do Supremo Tribunal Federal. Todos esses agentes eram "paradigmas máximos", faltando um referencial nacional unitário. Essa lacuna deu ocasião a diversos abusos, especialmente na esfera estadual e municipal, tendo motivado a promulgação da Emenda Constitucional $n^{\circ} 1$, de 31 de março de 1992, ocupada na fixação de subtetos específicos para deputados estaduais e vereadores. 
1590/SP. Rel. Min. SEPÚlVEDA PERTENCE, DJ 15-08-97, pp. 37.034, julgado em 19/06/1997 — Tribunal Pleno);

b) teto de retribuição, no Executivo, é a remuneração dos Ministros de Estado atribuída ao cargo por decreto-legislativo (CF, art. 49, VIII), não os valores que mediante opção, percebe efetivamente algum dos seus titulares, em razão de ser parlamentar ou servidor público efetivo (STF, RMS-21946/AL, Rel. Min. SEPÚLVEDA PERTENCE, DJ 01/07/94, p. 17.500);

c) o princípio da equivalência dos tetos de remuneração é extensivo aos Estados-membros, Distrito Federal e Municípios (STF, AGRAG-189.110/SC, Rel. Min. MARCO AURELIO, DJ 28/1 1/97, pp-62.224, Segunda Turma; STF, AO170/GO, Rel. Min. CARLOS VELLOSO, DJ 04/04/97, pp-10.519, 08/02/1996; AGRAG-194042-SC, DJ 15/05/98, pp-00048; RE 0228080-SC, DJ 21-08-98 pp-00026);

d) os limites de remuneração dos servidores ativos é também aplicável aos proventos e às pensões pagas segundo o regime previdenciário especial dos servidores públicos (STF, RE-118024/SP, Rel. Min. OCTÁVIO GALLOTTI, DJ 03/04/92, pp-04291, RTJ VOL-00141-01, pp-00264, 18/02/1992, Primeira Turma, STF, RE-115807, RTJ-127/290; STF, RE-11227; STF, RMS 21.856-1, Rel. Min. CELSO DE MELLO, Informativo 10; STF, RE-161263/CE, Rel. Min. MAURÍCIO CORREA, 11/04/1995, Segunda Turma, DJ 19/05/95, pp-14002; STJ, MS n ${ }^{\circ}$ 2.517-7 - DF, Rel. Min. JOSÉ DANTAS, em 07/10/93, $3^{\mathrm{a}}$ Seção, R. Sup. Trib. Just., Brasília, a, 6, (58): 105-111 junho 1994 p. 107);

e) a União, os Estados e Municípios podem estabelecer subtetos por lei, isto é, limites de remuneração inferiores aos valores percebidos pelos paradigmas referidos na Constituição (STF, RE 228.080-SC, Rel. Min. SEPÚLVEDA PERTENCE; STJ, ROMS n ${ }^{\circ}$ 1.290-PR, Rel. Min. DEMÓCRITO REINALDO, DJU 26/04/93; STF, ARAI 178.072/MG, Rel. Min. MARCO AURÉLIO, DJ 9/5/1997, Segunda Turma; STF, ARAI 192.870/MG, Rel. Min. MARCO AURÉLIO. DJ 6/2/1998; ADI 1.396-3, Rel. Min. MARCO AURÉLIO, Informativo N. 117);

f) a fixação de limites máximos de remuneração é matéria sujeita à reserva de lei, descabendo disciplina mediante decreto do Poder Executivo (STF, ADI 482-RJ, Rel. Min. NERI DA SILVEIRA; ADIMC 1396, Rel. Min. MARCO AURÉLIO);

g) os limites máximos de remuneração são aplicáveis também às empresas públicas e sociedades de economia mista (STF, ADIn 787-pr, Rel. Min. OCTÁVIO GALLOTTI; ADIMC-906-PR, Rel. Min. CARLOS VELLOSO);

h) a violação do princípio da equivalência, por eventual diferença entre a remuneração dos Ministros de Estado e Ministros do Supremo, não permite que 
o servidor do Poder Executivo obedeça apenas ao limite eventualmente maior dos Ministros do Supremo; esta situação configura inconstitucionalidade por omissão relativa, que não admite suprimento judicial (STF, ADIN 539, 16/9/91, Rel. Min. SEPÚLVEDA PERTENCE, LEX 175/90; STF, RE 228080/SC, Rel. Min. SEPÚLVEDA PERTENCE, Tribunal Pleno, s.d.); em sentido contrário, admitiu-se a distinção entre teto real e teto formal, para o fim de reconhecer aplicação de teto em valor superior decorrente da aplicação do princípio da equivalência dos tetos (STF, AG. REG. 189110, Rel. Min. MARCO AURELIO, DJ DATA-28/11/97 pp-62224 EMENT VOL-01893-03 pp-00643);

i) as vantagens pessoais devem ser excluídas do limite máximo de remuneração (STF, RE 185.842/PE, Rel. Acórdão MAURÍCIO CORREIA, j. 6/11/1996, publicação DJ 02/05/1997 pp-16.568; RE-S61263/CE, Rel. Min. MAURÍCIO CORREIA, J. 11/04/1995-Segunda Turma, Publicação DJ 19/05/1995, pp1.402; RE 141788, RMS 21.841, RMS 21.857, RMS 21.943, ADI 1.418, ADI 1443, RE 185.842, ADI 1597, ADI 356/RO, Rel. Min. OCTÁVIO GALLOTTI, 25.06.97 - TRIBUNAL PLENO, DJ 12/09/97, pp 43.713);

1.1) são vantagens pessoais:

i. 1.1.) adicional por tempo de serviço (STF, ADIn 14, Rel. Min. CÉLIO BORJA, DJ 01-12-89, pp-17759, 28/09/1989 - Tribunal Pleno, RTJ 130/475; STF, ADIMC1550/AL, Rel. Min. MAURÍCIO CORREA, DJ 04/04/97, pp-10519, 16/12/1996 Tribunal Pleno)

i.1.2) quintos, isto é, incorporação de parcela de cargo em comissão exercido (STF, RE 185842/PE, Rel. Acórdão MAURÍCIO CORREIA, j. 6/11/1996, publicação DJ 02/05/1997, p. 16.568)

i.1.3) estabilidade financeira, vantagem que garante ao servidor efetivo, depois de determinado tempo de exercício de cargo em comissão ou assemelhado, a continuidade da percepção dos vencimentos dele, ou melhor, da diferença entre estes e o do seu cargo efetivo (STF, ADIn MG, 1279, 27/9/95, Rel. Min. MAURíCO CORREIA, DJ 15/12/95; RE 201499, $1^{*}$ Turma, 24/4/98, Rel. Min. SEPÚLVEDA PERTENCE; ADIMC-1264/SC, Rel. Min. SEPÚlVEDA PERTENCE, J. 25/05/1995, Publicação DJ 30/06/95, pp. 20404; RE 195886, 1 t., 2/9/97, Rel. Min. ILMAR GALVÃO; RE 193810, $1^{\text {a }}$ Turma, Rel. Min. MOREIRA ALVES, Informativo 66 e 74, RE 218989, $1^{2}$ Turma 9.12.97. Rel. Min. ILMAR GALVÃO; Re 197739/SC, $1^{\text {a }}$ Turma, Rel. Min. SEPÚLVEDA PERTENCE).

i.1.4) adicional na aposentadoria (art. 174 da Lei 1.711);

i.1.5) gratificação de gabinete e função incorporadas (ADIMC 1.344-AL, DJU de 19/4/96; ADIMC 1.833-PE (julgado em 27.5.98), não publicado, v. Informativo 112; RE 226.473-SC (julgado em 13/5/98, não publicado, v. Informativo 110); RMS 21.840-DF (RTJ 156/518); RE 220.397-SP, rel. Min. ILMAR GALVÃO, 9/12/98 (Informativo 135); RE 220.397-SP, rel. Min. ILMAR GALVÃO, 9/12/98. (Informativo 135)

i.1.6) gratificação de risco de vida, correspondente à natureza do trabalho (STF, RE No 218.465-PR, Rel. Min OCTÁVIO GALLOTTI, Informativo n 131). 
i.2) não são vantagens pessoais:

i.2.1) gratificação de produtividade e retribuição adicional variável (RAV) (STF, RE-185842/PE, OCTÁVIO GALLOTTI, Rel. Acórdão MAURICIO CORREA, DJ 02/05/97, pp-16568, 06/11/1996 - Tribunal Pleno).

i.2.2.) as vantagens de função gratificada, representação de gabinete, cargo em comissão, de função gratificada e de tempo integral (STF, RE No 218.465-PR, Rel. Min OCTÁVIO GALLOTTI, Informativo No 131), consideradas não pessoais "por serem correspondentes ao exercício do cargo ou função, independentemente de quem seja o titular ou do que anteriormente ele tenha sido" (STF, ADIMC-1344 / ES, Rel. Min. MOREIRA ALVES, DJ 19/04/96, pp-12212, 18/12/1995 - Tribunal Pleno);

i.2.3.) verba de honorários advocatícios (STF, RE 220.397-SP, ILMAR GALVÃO, 9/12/98 (Informativo 135)

i.2.4.) indenizações de habilitação (STF, AGRSS-530/CE, Rel. Min. OCTÁVIO GALLOTTI, DJ DATA-24/09/93 pp-19.574 EMENT VOL-01718-01 pp-00001, 02/08/1993 - Tribunal Pleno)

$\mathrm{Na}$ linha dessas decisões, mas sem critério, várias parcelas remuneratórias foram sendo excluídas também pelo Legislador. No âmbito da União, a Lei 8.112/1990 excluía seis parcelas remuneratórias da incidência de teto de remuneração; poucos anos depois, a Lei $n^{\circ} 8.448 / 92$ já referia a quinze exclusões e a Lei 8.852/94 previa nada menos de dezessete exclusões, algumas mencionadas em cláusulas abertas, a exemplo da permissão, dada ao Poder Executivo, para reconhecer, no âmbito das empresas públicas e sociedades de economia mistas, novas exceções mediante acordo ou negociação coletivas. No Poder Judiciário, a par disso, era usual que as condenações judiciais determinassem que a condenação pecuniária deferida deveria ser considerada "vantagem individual", por haver sido concedida em "termos individuais", sendo excluída das contenções do teto de remuneração. Esse último absurdo não contava com aval do Supremo Tribunal Federal (cf. STF, RE-218465-PR, Rel. Min. OCTÁVIO GALLOTTI, Data do Julgamento: 23/06/1998, DJ DATA-13/1 1/98 PP-00016 EMENT VOL-01931-06 PP-01132; AGRSS-733, Rel. Min. OCTÁVIO GALLOTTI).

O teto estava desmoralizado. De direito rígido (hard law), passara a flexível (soft law). Sofrera mutação. Concluída a mutação constitucional, constava-se que a Constituição fora alterada como norma, independente da alteração de seu texto. De norma limitativa de toda e qualquer parcela de remuneração, "a qualquer título", a lei fundamental, nesta parte, assumira a condição de norma claudicante, porosa, aberta a um sem número de exceções, sem qualquer eficácia para conter remunerações casuísticas de valor vultoso.

Mas não se pense que a definição do teto constitucional de remuneração assumiu alguma vez qualquer relevância maior sob o ponto de vista fiscal. Os casos de remuneração escandalosa sempre foram isolados. Em geral, os servidores públicos ganham mal e não são afetados por qualquer teto de remuneração. A questão tem contornos unicamente morais e jurídicos. As contas públicas não são reequilibradas com nenhum teto de remuneração. No entanto, a opinião pública exige, cada dia com maior impaciência e inflexibilidade, contenção e comedimento no gasto público. 
A Emenda Constitucional $\mathrm{n}^{\circ} 19$ procurou oferecer uma resposta a este estado de coisas e, de certo modo, confirmar o que a doutrina especializada afirmava ser a intenção do constituinte de 1988 em torno da fixação dos limites máximos de remuneração; a fixação de limites de remuneração, intransponíveis "a qualquer título". É um dos paradoxos da emenda: ocupou-se em alterar o texto da Constituição para confirmar o escopo de normas da Constituição de $1988 .{ }^{10}$

O texto central é novamente o art. $37, \mathrm{XI}$, com nova redação:

“Art. 37 (...)

XI — a remuneração e o subsídio dos ocupantes de cargos, funções e empregos públicos da administração direta, autárquica e fundacional, dos membros de qualquer dos Poderes da União, dos Estados, do Distrito Federal e dos Municípios, dos detentores de mandato eletivo e dos demais agentes políticos e os proventos, pensões ou outra espécie remuneratória, percebidos cumulativamente ou não, incluídas as vantagens pessoais ou de qualquer outra natureza, não poderão exceder o subsídio mensal, em espécie, dos Ministros do Supremo Tribunal Federal."

Para o novo sistema também foi formulada disposição transitória, nos seguintes termos:

10 O trecho diz respeito ao "primeiro paradoxo" referido na exposição que fiz no Congresso Brasileiro de Direito Administrativo, realizado na cidade de Curitiba, em painel de 09/09/1996, intitulada: "A Reforma Administrativa e seus Três Paradoxos". Tratava-se de uma afirmação provocativa, cujo propósito era claro: romper com a unilateralidade dos discursos a favor e contra a proposta de emenda constitucional. Sempre identifiquei méritos e defeitos graves no texto dos projetos relativos à reforma administrativa em curso no Congresso Nacional e, antes disso, no Poder Executivo. A síntese final de uma proposta de emenda constitucional é sempre uma síntese política. Lamentava, de público, no entanto, que a unilateralidade de posições ocultasse do debate público questōes técnicas sérias, como os limites de aluaçāo dos Relatores dos Projetos de Emenda Constitucional no Congresso Nacional. Entendia, como ainda entendo, que os relatores excedem em muito os seus limites de atuação, modificando e sugerindo modificaçōes nos projetos de emenda constitucional em curso com grande desenvoltura, sem amparo constitucional. Deveriam comportar-se como simples relatores, consolidando propostas feitas por um terço dos deputados ou senadores, pelo Presidente da República ou pela maioria das Assembléias Legislativas, os únicos agentes legítimados pela Constituição para deflagrarem o processo de emenda constitucional (CF, art. 60). Na verdade, comportam-se como se fossem legitimados a inovar individualmente no processo, a qualquer tempo, antes da votação final na comissão competente. Esse fato, desconsiderado ainda hoje, passados tantos anos, importa também numa consequiência de ordem política: menor transparência nos processos de aprovação de emendas constitucionais e maior insegurança jurídica. 
“Art. 30. "Os subsídios, vencimentos, remuneração, proventos de aposentadoria e pensões e quaisquer outras espécies remuneratórias adequar-se-ão, a partir da promulgação desta emenda, aos limites decorrentes da Constituição Federal, não se admitindo a percepção do excesso a qualquer título".

No novo sistema, é simplificado e enrijecido radicalmente o sistema de fixação de limites de retribuição. É estabelecido um único teto nacional, correspondente ao subsídio dos Ministros do Supremo Tribunal Federal. Prefeitos, Governadores, Ministros de Estado, Deputados e Senadores, o próprio Presidente da República, não poderão perceber mais do que for definido como subsídio dos Ministros do Supremo Tribunal Federal. No cálculo do teto serão consideradas as vantagens pessoais e toda e qualquer parcela de remuneração. Além disso, nas hipóteses de acumulação, tanto de provento quanto de remuneração, as parcelas serão somadas e consideradas como um todo unitário para fins de abatimento.

A soma das acumulações constitucionais para fins de abate-teto não tem justificativa que a sustente. Nada representa do ponto de vista fiscal ou moral. No plano jurídico, de revés, provoca perplexidade, pois consta da Constituição Federal norma que autoriza os próprios ministros do Supremo Tribunal Federal a acumulação "remunerada" decorrente do exercício de outra função pública (ensino). Fica-se numa situação antinômica: uma norma autoriza a acumulação remunerada, permitindo aos ministros perceberem do Poder Público valores adicionais ao subsídio devido pelo exercício de seus cargos no Poder Judiciário, mas outra norma, a relativa ao teto, aparentemente impede qualquer percepção de valor adicional. A solução terá de ser jurisprudencial, evitando a antinomia interna na lei fundamental, segundo o princípio da unidade da Constituição, provavelmente pela saída interpretativa de considerar o teto aplicável a todos os agentes públicos, ressalvados os ministros do Supremo Tribunal Federal, por serem os próprios paradigmas nesta matéria. Solução incômoda, autêntica lacuna axiológica, mas aparentemente a única solução do ponto de vista lógico."

No entanto, no novo regime não há mais a possibilidade de fixação de um subteto fixo, definido em termos nominais ou mediante a aplicação de percentual redutor. Poderão apenas ser fixados subtetos móveis, no âmbito da União, dos Estados, do Distrito Federal e dos Municípios, mediante a definição da relação entre

11 Em sentido contrário, JESSE TORRES PEREIRA JUNIOR propõe uma "exgese conciliatória" diversa restringe a proibição da percepção cumulativa ao âmbito de cada carreira, admitindo que quando a acumulação corra entre cargos de carreira distintas podem superar o valor fixado para $o$ teto (De Reforma Administrativa Constitucional, Rio de Janeiro, Renovar, 1999, p. 120). A solução não convence: atenderia as hipóteses de acumulação dos magistrados e membros do ministério público, mas não resolveria a questão para os que estão autorizados a acumular (a) dois cargos de professor, (b) dois cargos privativos de médico: (c) dois cargos ou empregos privativos de médico militar que estivessem sendo exercidos na data da promulgação da Constituiçāo; (d) dois cargos ou empregos privativos de profissionais de saúde que estivessem sendo exercidos na data da promulgação da Constituição. Essa solução interpretativa importa também em "lacuna axiológica". pois trata as acumulações de modo desigual, conforme sejam exercidas ou não na mesma carreira. 
a menor e a maior remuneração dos servidores públicos, e apenas para eles, sempre a partir de lei ordinária e considerada a iniciativa privativa em cada caso, do Poder Executivo, Legislativo e Judiciário, bem como do Ministério Público, obedecido o limite máximo constitucional. Este subteto está previsto em outra disposição da emenda, que acrescentou um $\S 5^{\circ}$ ao art. 39 da Constituição Federal, e será analisado em detalhe adiante.

Sobremais, o novo teto é aplicável ordinariamente apenas para a administração . direta, autárquica e fundacional, somente incidindo sobre as empresas públicas $e$ sociedades de economia mista, ou suas subsidiárias, quando estas entidades recebem recursos da União, dos Estados, do Distrito Federal ou dos Municipios para pagamento de despesas de pessoal ou custeio em geral (art. $37, \S 9^{\circ}$, introduzido pelo art. $3^{\circ}$ do Substitutivo).

$\mathrm{O}$ fato de atualmente o teto constitucional incluir expressamente as vantagens pessoais e. ademais, as acumulações constitucionais, aparentemente torna o teto absoluto. Na verdade, a resposta é negativa, se se pensa em todas as parcelas percebidas pelos agentes públicos; positiva, se se pensa em termos de parcelas mensais, gerais e permanentes componentes da remuneração dos agentes públicos. Vamos tentar precisar esse ponto.

\section{Parcelas excluidas dos limites máximos no novo regime constitucional}

A rigidez do novo sistema não pode ser compreendida contra a própria administração pública e contra princípios que remarcam a inteligência do sistema jurídico. $\mathrm{Na}$ verdade, as parcelas percebidas pelos servidores públicos que não constituírem remuneração. ou subsídio, mas simples indenizações não poderão ser computadas para fins de cálculo do abate-teto.

As indenizações não poderão ser consideradas no limite constitucional de remuneração por razões singelas:

a) em razão do princípio da igualdade, pois se despesas adicionais e trabalho adicional não autorizarem ressarcimento ou compensações, haveria desequilibrio de situações jurídicas (ex. direito de utilização de apartamento funcional e direito a ressarcimento de despesa com moradia se inexiste apartamento funcional disponível; despesas de diária, locomoção etc.);

b) pela razão de que as parcelas indenizatórias não integram, a todo rigor, a remuneração do agente público, constituindo valores pagos em caráter eventual (ex. diárias de viagem), não devendo integrar os limites constitucionais de remuneração.

O conceito de indenização não é elástico, vago ou fluído na medida do conceito das famosas "vantagens pessoais".

As indenizações são valores ou vantagens pecuniárias que apresentam as seguintes caracteristicas definitórias:

a) são eventuais (não são necessárias, ou inerentes, ao exercício do cargo público, mas decorrentes de fatos ou acontecimentos especiais previstos na norma); 
b) são isoladas, não se incorporando ou integrando aos vencimentos, subsídios ou proventos para qualquer fim;

c) são compensatórias, pois estão sempre relacionadas a acontecimentos, atividades ou despesas extraordinárias feitas pelo servidor ou agentes pelo exercício da função;

d) são referenciadas a fatos e não à pessoas do servidor.

Exemplos de parcelas indenizatórias:

a) diárias:

b) ajuda de custo de mudança;

c) auxílio moradia, na forma de ressarcimento, quando inexiste apartamento funcional disponível;

d) remuneração do serviço extraordinário, que a própria Constituição obriga que seja superior, no mínimo, em cinqüenta por cento à do normal;

e) "gratificações eleitorais", na verdade, parcelas percebidas em caráter compensatório por agente em função especial temporária, paralelamente ao exercício de função permanente, sem possibilidade de incorporação ao provento, vencimento ou subsídio.

A exclusão das parcelas indenizatórias da consideração do limite de remuneração não é uma construção artificial. Na verdade, a própria emenda 19 sugere a exclusão quando trata do pagamento da indenização do parlamentar que comparece à sessão legislativa extraordinária. Segundo o art. $57, \S 7^{\circ}$, da Constituição, com a redação que lhe deu a emenda:

“Art. 57.

“ $\S 7^{\circ} \mathrm{Na}$ sessão legislativa extraordinária, o Congresso Nacional somente deliberará sobre a matéria para a qual foi convocado, vedado o pagamento de parcela indenizatória em valor superior ao do subsídio mensal."

Ora, se o subsídio é uma espécie de retribuição pecuniária definida em termos tendencialmente completos, pois recusa qualquer outra vantagem, adicional, gratificação ou abono, ressalvadas as vantagens adicionais autorizadas pela Constituição (art. 39, $\S 3^{\circ} ; \mathrm{c} / \mathrm{c}$ art. $7^{\circ}$, da $\mathrm{CF}$ ); se, por essas qualidades de transparência e fixidez, foi eleito para referenciar o teto de retribuição (os subsídios dos Ministros do Supremo); quando a Constituição permite sua acumulação, no período da sessão legislativa extraordinária, com parcela compensatória dessa ocupação adicional ou serviço extraordinário, qualificando expressamente essa parcela como indenização, parece plausível inferir que as indenizações escapam ao conceito constitucional de remuneração e devem ser consideradas vantagens extraordinárias imunes ao teto.

Não fosse assim, o servidor próximo ao teto teria de arcar, por exemplo, com despesas eventuais e extraordinárias de viagem sem ressarcimento do Estado, criando situações de enriquecimento sem causa do erário público completamente sem sentido e manifestamente injustas. 


\section{Previsão de limites inferiores ao teto constitucional nacional (subteto)}

A emenda constitucional 19 retirou do texto constitucional a competência para fixação dos limites nominais máximos de remuneração mediante lei. Mas manteve a previsão de estabelecimento de uma relação entre a menor e maior remuneração, deslocando a matéria para o art. $39, \S 5^{\circ}$, com a seguinte redação:

“Art. 39. (...)

$\S 5^{\circ}$. "Lei da União, dos Estados, do Distrito Federal e dos Municípios poderá estabelecer a relação entre a maior e a menor remuneração dos servidores públicos, obedecido, em qualquer caso, o disposto no art. 37, XI."

O dispositivo transcrito possui a finalidade do subteto móvel previsto na redação original da Constituição Federal, constante da parte inicial do art. 37, XI. Num e noutro preceito o que se pretende é evitar disparidades excessivas entre a menor e a maior remuneração dos servidores públicos, com o estabelecimento de limites. Estes limites, mínimos e máximos, ficam atrelados, o que termina por atribuir aos valores uma natureza "móvel" (ex. aumento do salário mínimo, aplicável também ao servidor público, aumenta o limite máximo de remuneração). Fixa é apenas a relação entre os limites mínimos e máximos de remuneração, não os valores nominais resultantes.

O texto aprovado deixa claro no art. $39, \S 5^{\circ}$, que as leis que estabelecerem a "relação entre a maior e a menor remuneração" devem obedecer, em qualquer caso, o disposto no art. 37, XI (teto). Ora, se a relação entre a menor e a maior remuneração tivesse necessariamente de produzir o mesmo efeito da aplicação do teto previsto no art. 37, XI, a disposição sobre os limites mínimos e máximos seria ociosa, redundante, descritiva e não prescritiva. Não se pode postular, entretanto, que a Constituição estabeleça normas inúteis. A relação entre a menor e a maior remuneração, por isso, pode estabelecer limites máximos inferiores ou iguais ao teto constitucional estabelecido, bastando que a relação definida conduza a este resultado nominal. Mas o alcance do subteto móvel, no novo sistema, é inferior ao da redação original do art. $37, \mathrm{XI}$.

Com a emenda constitucional $n^{\circ} 19$, o sistema constitucional de fixação do teto passa a ser analítico. Na nova redação do art. 37 , XI, não se menciona mais a "servidores públicos", em sentido genérico, mas a "servidores públicos", "agentes políticos" e a "membros do poder", muitas vezes de forma redundante. Não se aponta apenas a existência de limites, mas quais são eles (faz-se a inclusão das vantagens pessoais, das acumulações constitucionais e das parcelas de qualquer natureza). Essa nova postura do legislador não pode ser desconsiderada na interpretação da nova redação do dispositivo sobre fixação da relação entre a menor e a maior remuneração. Nesta regra, de forma intencional ("teoria do silêncio eloqüente"), o legislador não incluiu as acumulações constitucionais nem fez referência às vantagens pessoais, restringindo-se a mencionar apenas os servidores públicos. $\mathrm{Na}$ nova regra, portanto, diante do contexto sistemático em que ela se move, não estão 
incluídas as vantagens pessoais, nem as acumulações, nem mencionados os agentes políticos e membros de poder, mas apenas os servidores públicos. Tudo isso lhe diminuirá o impacto e a importância.

6. Diferenças e semelhanças entre o novo sistema e o previsto originalmente pela Constituição de 1988

Essas considerações permitem identificar diferenças e semelhanças entre os tetos de remuneração na redação original e na redação da emenda constitucional $\mathbf{n}^{\circ} 19$.

No texto original, existem três limites máximos de remuneração na União, no Distrito Federal e nos Estados e um nos Municípios. No texto reformado, há um único teto constitucional nacional: o valor definido para subsídio dos Ministros do Supremo Tribunal Federal. A redação do texto original permitiu ainda a que se falasse em princípio da paridade ou equivalência dos tetos constitucionais, mecanismo de iludir o princípio que exigia aumento por lei específica, o que termina com a nova redação.

No texto original, embora fossem afirmados limites máximos capazes de conter os valores percebidos como remuneração, a qualquer título, deixava-se escapar, por interpretação conjugada do art. $37 . \mathrm{XI}$, com o art. $39, \S 1^{\circ}$, as vantagens pessoais (individuais) e as relativas à natureza ou ao local de trabalho. No novo sistema estão incluídas expressamente na consideração do teto de remuneração as vantagens pessoais ou de qualquer outra natureza.

No regime original, a aplicação do teto era feita para cada cargo isolado ou provento, desconsiderando-se eventuais situações de acumulação. No novo texto, as acumulações constitucionais, de qualquer natureza, inclusive de proventos, de pensões e vencimentos, são somadas para se obter um valor total que é contido nos limites do teto.

No texto original, como no texto reformado, são apresentadas disposições transitórias que afastam a invocação do direito adquirido quanto à aplicação do teto constitucional. No texto reformado, passa a constar expressamente também referência às pensões, não mencionadas explicitamente no art. 17 do ADCT, embora considerada implícita pela jurisprudência do Supremo Tribunal Federal.

No texto original, era permitido à lei ordinária, da União, dos Estados do Distrito Federal e dos Municípios a fixação de subtetos nominais, ou limites inferiores ao teto constitucional máximo de forma abrangente, alcançando todos os agentes públicos (segundo entendimento do Supremo Tribunal Federal). Além disso, era autorizada a fixação de subtetos móveis, mediante a fixação de uma relação a ser respeitada entre a menor e maior remuneração. No novo texto, não é mais permitida a fixação de subteto nominal, o que diminui a flexibilidade do sistema na Federação. Permite-se apenas a fixação de subteto móvel, mas em termos mais limitados, alcançando apenas os servidores públicos e sem a consideração das vantagens pessoais e das acumulações constitucionais.

O novo teto produziu problemas graves, especialmente por contabilizar as acumulações constitucionais. Além de desestímulo profissional para pessoas quali- 
ficadas, próximas ao teto, a restrição, se não for objeto de imediata modificação ou temperamento jurisprudencial, importará uma contradição clara entre normas constitucionais. Ademais, criou-se a extravagância de uma lei de iniciativa conjunta do Presidente da República, do Presidente do Supremo Tribunal Federal e dos Presidentes da Câmara e do Senado Federal para definição do valor do teto constitucional nacional, correspondente ao subsídio dos Ministros do Supremo Tribunal Federal.

\section{A posição do Supremo Tribunal Federal sobre a eficácia das novas disposições constitucionais sobre teto de retribuição}

No dia 24 de junho de 1998, o Supremo Tribunal Federal, em sessão administrativa, ao ser indagado pelos presidentes da Câmara dos Deputados e do Senado Federal sobre o maior valor remuneratório dos seus membros, para aplicação do teto constitucional (art. 37, XI), respondeu o seguinte:

"O SUPREMO TRIBUNAL FEDERAL, reunido em sessão administrativa, deliberou por 7 votos a 4, vencidos os Ministros Sepúlveda Pertence, Carlos Veloso, Marco Aurélio e Ilmar Galvão, que não é auto-aplicável a norma constante do art. 24 da Emenda Constitucional $n^{\circ} 19 / 98$, por entender que essa regra depende. para efeito de sua plena incidência e integral eficácia, da necessária edição de lei, pelo Congresso nacional, lei essa que deverá resultar de projeto de iniciativa conjunta do Presidente da República, do Presidente da Câmara dos Deputados, do Presidente do Senado Federal e do Presidente do Supremo Tribunal Federal.

O Supremo Tribunal Federal nessa mesma sessão administrativa, entendeu que, até que se edite a lei definitiva do subsídio mensal a ser pago a Ministro do Supremo Tribunal Federal, prevalecerão os três (3) tetos estabelecidos para os três poderes da República, no art. 37, XI da Constituição, na redação anterior à que lhe foi dada pela EC 19/98, vale dizer, no Poder Executivo da União, o teto corresponderá à remuneração paga a Ministro de Estado; no Poder Legislativo da União, o teto corresponderá à remuneração paga aos membros do Congresso Nacional; e no Poder Judiciário, o teto corresponderá à remuneração paga atualmente, a Ministro do Supremo Tribunal Federal.

O Supremo Tribunal Federal na Sessão administrativa hoje realizada declarou que não dispõe de competência, para, mediante ato declaratório próprio, definir o valor do subsídio mensal. Essa é matéria expressamente sujeita à reserva constitucional de lei em sentido formal."

As razões motivadoras da indagação feita pelos Presidentes da Câmara e do Senado Federal eram conhecidas: 
a) incerteza quanto ao valor do novo teto, pois discutia-se se o valor era o fixado para a remuneração dos Ministros do Supremo, incluídas todas as vantagens do cargo ( $R \$ 10.800$ ) ou esse valor deveria ser acrescido da gratificação eleitoral percebida, em caráter temporário, por três ministros do Supremo Tribunal Federal em exercício no Tribunal Superior Eleitoral (totalizando R\$12.720);

b) incerteza quanto a eficácia imediata do novo valor do teto, tendo em vista as limitações que o novo valor trazia, somando as acumulações constitucionais e os proventos de aposentadoria para fins do abate-teto, bem como a exigência de lei formal conjunta para definição dos subsídios dos Ministros do Supremo Tribunal Federal e a ausência de norma transitória específica sobre a matéria.

Sobre esse tópico, no entanto, desde a promulgação da emenda, tenho sustentado entendimento radicalmente distinto do adotado pelo Colendo Supremo Tribunal Federal.

Os argumentos podem ser resumidos nos seguintes:

a) a norma do art. 37, XI, com a redação dada pela Emenda Constitucional $\mathrm{n}^{\circ}$ 19 é auto-aplicável, no plano federal, estadual e municipal e no Distrito Federal, porque dotada de suficiente densidade normativa, independentemente da promulgação da lei a que seu texto alude, à semelhança do que entendera o Supremo Tribunal Federal em relação ao art. 37, XI, na redação primitiva da Constituição (STF, ADIMC-1590/SP. Rel. Min. SEPÚLVEDA PERTENCE, DJ 15/08/97, pp. 37.034, julgado em 19/06/1997 - Tribunal Pleno);

b) a maior remuneração paga a Ministro do Superior Tribunal Federal, por ocasião da promulgação da emenda constitucional $n^{\circ} 19$ deve ser tida como paradigma, para fins de aplicação do novo teto de remuneração;

c) as "gratificações eleitorais" pagas a três ministros do Supremo Tribunal Federal, em caráter temporário, pelo exercício de funções no Tribunal Superior Eleitoral não integram a remuneração do cargo de Ministro do Supremo Tribunal Federal, constituindo vantagem indenizatória pelo exercício concomitante de função diversa, com acréscimo de tarefas, não sendo de incorporar ao subsídio devido pelo cargo efetivo de Ministro do STF, nem ter o seu pagamento suspenso pela definição do referido subsídio ao teto;

d) a consideração das acumulações de vencimentos ou de vencimentos e proventos para fins de abate-teto deve ser objeto de temperamentos interpretativos ou de rápida supressão, por via de emenda constitucional, tendo em vista a necessidade de conferir sentido útil às normas que autorizam a "acumulação remunerada" na Constituição, inclusive para os Ministros do Supremo Tribunal Federal (CF, art. 95, I); 
e) viola o princípio da separação dos Poderes, impedindo o exercício de uma das prerrogativas inerentes à autonomia do Poder Judiciário, a exigência de iniciativa conjunta dos Presidentes da República, do Supremo, da Câmara dos

Deputados e do Senado Federal para deflagração do processo legislativo de definição dos subsídios devidos aos Ministros do Supremo Tribunal Federal.

O último argumento merece uma consideração isolada, uma vez que tenta explicar porque, passados mais de dois anos da promulgação da emenda 19, não foi dada qualquer aplicação ao teto constitucional e há autêntico impasse na definição do subsídio dos Ministros do Supremo Tribunal Federal.

\section{Impasse na definição do teto constitucional}

O impasse para a definição do teto não diz respeito ao valor a ser fixado. Esta é apenas a parte visível da discussão. $O$ impasse resulta basicamente da exigência de um concerto absoluto, um entendimento prévio, formal, entre o Presidente da República, o Presidente do Supremo Tribunal Federal; o Presidente da Câmara dos Deputados e do Senado Federal sobre o projeto de lei fixador dos limites. É a exigência da "iniciativa conjunta" para fixação dos subsídios dos ministros do Supremo Tribunal Federal, contemplada no art. 48, inciso XV, da Lei Fundamental, a razão primeira do dissídio na matéria. Trata-se de uma disposição anômala, introduzida na Câmara dos Deputados durante a tramitação da emenda constitucional da reforma administrativa, objeto permanente de questionamento das assessorias técnicas da Câmara, do Senado e do Executivo. Por ela é possível a qualquer das autoridades envolvidas na discussão do tema uma espécie de "recusa prévia", obstaculizadora de qualquer iniciativa das demais autoridades envolvidas. Basta que uma das autoridades recuse a sua assinatura ao projeto de lei e o impasse se afirma. A norma criou um esdrúxulo "veto a projeto de lei". Mais do que isso: retirou do Supremo Tribunal Federal a iniciativa privativa de lei para definição da retribuição dos seus membros com repercussão direta para o restante da magistratura.

Como é sabido, segundo o art. 96, inciso II, alínea b, da Constituição da República, compete privativamente ao Supremo Tribunal Federal, aos Tribunais Superiores e aos Tribunais de Justiça propor ao Poder Legislativo respectivo, a criação e a extinção de cargos e a remuneração dos seus serviços auxiliares e dos juízos que lhes forem vinculados, bem como a fixação do subsídio de seus membros e dos juízes, inclusive dos tribunais inferiores. A norma faz apenas uma ressalva: o disposto no art. 48, XV (a fixação, por iniciativa conjunta, do subsídio dos ministros do STF). Essa ressalva do art. $96 \mathrm{e}$ a iniciativa conjunta prevista no art. 48 devem ser objeto de expurgo constitucional, vale dizer, de declaração de inconstitucionalidade, com fundamento no princípio da separação dos Poderes, restabelecendo-se a iniciativa reservada da Suprema Corte na matéria.

É óbvio que qualquer iniciativa do Supremo Tribunal Federal, quanto à definição do subsídio dos ministros da corte, como as demais hipóteses referentes à magistratura, exige votação nas duas casas legislativas e sanção ou veto pelo Poder Executivo. 
Mas o que resvala para a ilegitimidade constitucional é a exigência de que a própria iniciativa do projeto de lei dependa da concordância plena de todos os presidentes referidos. Como as divergências partidárias entre esses atores políticos são comuns, esse entendimento mútuo prévio e formal, fora do processo de discussão parlamentar, é praticamente inviável. Com a exigência formal, tolhe-se a iniciativa da corte na origem, acanhando desarrazoadamente as garantias da magistratura e violando diretamente a autonomia administrativa do Poder Judiciário. Torna-se letra morta a iniciativa privativa de lei prevista para os demais Tribunais (CF, art. 96. inciso II, alínea b), pois ela permanece indiretamente dependente da decisão unipessoal de chefes políticos de outros órgãos constitucionais. Constrangem-se princípios que nem mesmo uma emenda constitucional pode desconsiderar.

Essa compreensão do tema não é nova, nem resulta de uma "hermenêutica de interesse", de uma posição corporativa ou reativa, pois a venho sustentando há mais de dois anos em quase duas dezenas de congressos acadêmicos, e a apresentei, desde 1996, de forma privada, ao próprio relator da proposta de emenda constitucional na Câmara dos Deputados, Dep. Moreira Franco. É triste constatar, porém, que o problema continua praticamente no mesmo estado em que se encontrava há anos atrás.

O impasse, no entanto, é artificial, pois foi estimulado por norma inválida, que pode e deve ser removida mediante a plena restauração da ordem constitucional. Basta que as entidades ou as autoridades legitimadas para uma ação direta de inconstitucionalidade provoquem a Suprema Corte a eliminar a exigência de participação dos demais Poderes na iniciativa da lei fixadora do subsídio dos Ministros do Supremo Tribunal Federal. A Corte certamente preservará a autonomia da magistratura, elemento indiscutível e inegociável do Estado de Direito, criando condições para uma discussão mais democrática e serena do tema dentro do Congresso Nacional, segundo a regra da maioria e não segundo uma exigência prévia de unanimidade. ${ }^{12}$

\section{Impropriedade da fixação de tetos constitucionais estaduais}

A demora na definição de teto de remuneração previsto na Emenda Constitucional 19 tem ensejado algumas aventuras constitucionais no plano estadual.

No Estado da Bahia, a título de adaptar a Constituição do Estado às normas constantes da Emenda Constitucional 19, foi aprovada a Emenda Constitucional $\mathrm{n}^{\circ}$ 7. publicada no Diário Legislativo de 18.01.99, contemplando norma específica sobre a fixação de limites de remuneração no plano estadual. Reza o dispositivo.

12 Recentemente, a tese que sustentamos foi adotada pelo PARTIDO SOCIAL LIBERAL - PSL. que apresentou ação direta de inconstitucionalidade perante o Supremo Tribunal Federal sobre este específico ponto da Emenda Constitucional 19. Trata-se da Ação Direta de Inconstitucionalidade (Med. Liminar) 2.159-1, a ser relatada pelo Min. NÉRI DA SILVEIRA. Não houve ainda pronunciamento sobre o pedido de medida liminar ou o julgamento do mérito da ação. 
$\S 5^{\circ}$ a remuneração e o subsídio dos ocupantes de cargos, funções e empregos públicos da administração direta, autárquica e fundacional, dos membros de qualquer dos Poderes do Estado e dos Municípios, dos detentores de mandato eletivo e dos demais agentes políticos e os proventos, pensões ou outra espécie remuneratória, percebidos cumulativamente ou não, incluídas as vantagens pessoais ou de qualquer outra natureza, não poderão exceder o subsídio mensal, em espécie, dos Desembargadores."

O dispositivo transcrito, constante da emenda estadual, parece confundir o velho e o novo sistema de imposição de limites à remuneração dos agentes públicos.

No antigo sistema, ainda ultra-ativo pela negativa dada do Supremo Tribunal Federal à auto-aplicabilidade das novas normas constitucionais (cf. ADInMC 1.898DF, Rel. Min. OCTÁVIO GALLOTTI, 21/10/98), haviam tetos estaduais e um teto municipal, além dos limites previstos para a União. Entre os tetos estaduais, a retribuição dos desembargadores servia de limite apenas para os membros e servidores do Poder Judiciário. No entanto, os vencimentos dos desembargadores, mesmo no âmbito do Poder Judiciário, não limitava as vantagens pessoais nem considerava as acumulações constitucionais, segundo a jurisprudência firme do Supremo Tribunal Federal.

No atual sistema, pela nova redação do art. 37, XI, há apenas um teto nacional, o equivalente ao subsídio fixado para os Ministros do Supremo Tribunal Federal. A regra do atual art. 37. XI, ao contrário do que ocorria na redação original da lei fundamental, não menciona outros paradigmas para os Estados e Municípios. Muito menos a unificação do teto dos três poderes do Estado em um único referencial.

Não se trata de uma omissão. Na verdade, ao romper com o sistema anterior, que contemplava tetos diversos no interior da Federação, unificando o teto constitucional num paradigma nacional, a emenda constitucional $n^{\circ} 19$ derrogou o sistema anterior e contrastará imediatamente com qualquer tentativa de ressuscitá-lo.

A unificação do teto é medida extrema, polêmica mesmo no plano da reforma constitucional federal, na medida em que coloca o Poder Legislativo e o Poder Executivo na dependência da iniciativa do Poder Judiciário para a definição do valor do teto de remuneração dos seus respectivos servidores. No plano estadual esta regra não encontra paralelo e nem parece possível introduzi-la mediante emenda à Constituição Estadual.

Não se entende, portanto, como pretendeu a Emenda Constitucional Estadual $\mathrm{n}^{\circ} 7$ mesclar um sistema com o outro. Por um lado, conter expressamente no limite que estabelece os valores relativos a vantagens pessoais e acumulações constitucionais. Por outro, referir ao valor dos subsídios dos desembargadores, e não dos Ministros do STF, como teto para o plano estadual.

Não se diga que se trate de subteto estadual. Mais precisamente, um subteto nominal constitucional estadual. Não teria qualquer sentido. Primeiro, porque não mais existe na Constituição Federal autorização para edição de subtetos nominais pela União, os Estados, o Distrito Federal e os Municípios. Segundo, porque quando 
esta autorização existia ela referia ao veículo da lei, flexível, mutável, e não ao texto constitucional estadual. Terceiro, porque a previsão hoje existente para fixação de uma relação entre a maior e a menor remuneração exige lei especial, de iniciativa de cada um dos Poderes e do Ministério Público, não podendo esta iniciativa ser suprimida por emenda constitucional. Quarto, porque a previsão de fixação facultativa de subteto móvel, diferenciado em cada um dos Poderes e no Ministério Público, não autoriza a inclusão no seu cálculo das vantagens pessoais e das acumulações constitucionais, até pelo caráter diferenciado dentro e fora do Estado para os valores dos subtetos móveis. $O$ equívoco não deve ser seguido.

\section{Alteraçāo do novo teto constitucional}

O teto constitucional estabelecido pela Emenda Constitucional 19 corre o risco de ser revogado sem nunca ter sido implementado. Resultante de um complexo processo de negociação política, impulsionado pela opinião pública e por interesse políticos contraditórios, mostrou-se irrealista e demagógico, pouco flexível e de difícil operacionalização. Não são vícios desprezíveis e, o mais espantoso, não constavam da proposta original de emenda constitucional da reforma administrativa: foram adquiridos sobretudo pela iniciativa individual do Relator da Proposta de Emenda Constitucional da Reforma Administrativa na Câmara dos Deputados, personagem sem legitimação constitucional para iniciativas individuais em propostas de emenda constitucional (CF, art. 60).

Seja como for, as mudanças não tardaram: a Emenda Constitucional $\mathrm{n}^{\circ} 25$, de 14 de fevereiro de 2000 , estabeleceu nova sistemática de subtetos para os Vereadores Municipais, graduando o limite máximo de remuneração desses agentes ao número de habitantes do Município. A referida emenda, ainda, retornou à sistemática de exigir que o subsídio dos Vereadores seja fixado pela Câmara Municipal em cada legislatura para vigorar na subsequiente, medida restauradora que somente merece elogios. A Emenda $n^{\circ} 25$ entrará em vigor em $1^{\circ}$ de janeiro de 2001.

Nada obstante, as atenções se concentram hoje na Proposta de Emenda Constitucional 137-A, de $1999_{2}$ em curso no Congresso Nacional. Essa Proposta de Emenda, cuidando de modo praticamente exclusivo da revisão do sistema de fixação do teto constitucional de remuneração, altera e complementa a Emenda Constitucional $n^{\circ} 19$, corrigindo vários dos desvios apontados. Corre o risco, porém, de também fracassar, por não reunir o consenso político necessário para a sua aprovação.

No substitutivo aprovado de Relator, Deputado Vicente Arruda, constam propostas de modificação relevantes:

a) fixa-se subteto aplicável a toda remuneração, subsídio, provento e pensão devida por Estados, Distrito Federal e municípios equivalente ao subsídio do Governador do Estado, ressalvado o disposto nos arts. $27, \S 2^{\circ}, 29$, VI e 93, V, esvaziando parcialmente a importância do teto nacional vinculado ao valor do subsídio dos Ministros do Supremo Tribunal Federal; 
b) autoriza-se a fixação de subtetos por lei, observada a iniciativa dos Poderes e do Ministério Público, incluindo todas as vantagens pessoais ou de qualquer natureza;

c) exclui do conceito de remuneração, para os fins do abate-teto, as verbas inerentes ao exercício do mandato eletivo e eventual gratificação percebida por magistrado e membro do Ministério Público pela atuação na Justiça Eleitoral.

d) estabelece como valor de incidência imediata para fins de aplicação da norma de teto o correspondente à maior remuneração percebida por Ministro do Supremo Tribunal Federal, incluídas todas as vantagens pessoais e funcionais, desde logo arbitrando o valor em termos certos (R\$11.500);

e) recusa a soma do valor dos proventos, pensões e demais benefícios previdenciários com o valor da remuneração ou subsídio, dos servidores ativos, quando a acumulação for autorizada pela constituição e for exercida à data da promulgação da Emenda;

f) fixa escalonamento, ou subtetos específicos, para a estrutura do Poder Judiciário, definindo que os Ministros dos Tribunais Superiores perceberão noventa e cinco por cento do subsídio mensal dos Ministros do Supremo Tribunal, observando-se os mesmos limites percentuais nos demais escalões do Poder Judiciário.

O Substitutivo foi aprovado em 05/04/2000 e em 14/06/2000 foi encerrada a discussão dos destaques. A matéria irá a Plenário da Câmara dos Deputados para a votação em primeiro turno. Dois destaques aprovados, no entanto, retiraram do texto elementos importantes, que podem comprometer a sua aprovação em plenário: o primeiro, da bancada do PTB, excluiu referência às vantagens pessoais ou de qualquer outra natureza pelo subteto a ser definido por lei dos Estados, do Distrito Federal e dos Municípios; o segundo, da bancada do PSDB, retirou do texto norma que excluía dos efeitos da definição do novo valor de subsídio dos Ministros do Supremo Tribunal os juízes classistas de primeira instância, ativos ou inativos, bem como os seus pensionistas.

A discussão dessas propostas, difícil e demorada, demonstra bem a distância existente entre a racionalidade dos juristas e a necessidade de negociação pragmática que cerca todos os projetos de emenda constitucional sobre o assunto. Há consenso de que a mais precisa definição dos limites de remuneração no setor público constitui um imperativo ético, sem o qual é impossível conter hipóteses de apropriação da coisa pública por grupos restritos de agentes, especialmente nos estratos mais elevados do Estado. Mas esse consenso, infelizmente, não tem se mostrado suficiente para assegurar a efetividade das normas dedicadas ao tema. O teto constitucional de remuneração permanece incerto e sua definição prática continua sujeita a constantes mutações (por ação ou por omissão) e emendas constitucionais. Trata-se de tema ainda em aberto, cuja crônica instrui e incomoda, sem que se possa antecipar qualquer desfecho ou solução de consenso em curto prazo. (Salvador, 04/08/2000) 


\section{O Direito à Defesa na Constituição de 1988}

Jessé Torres Pereira Junior

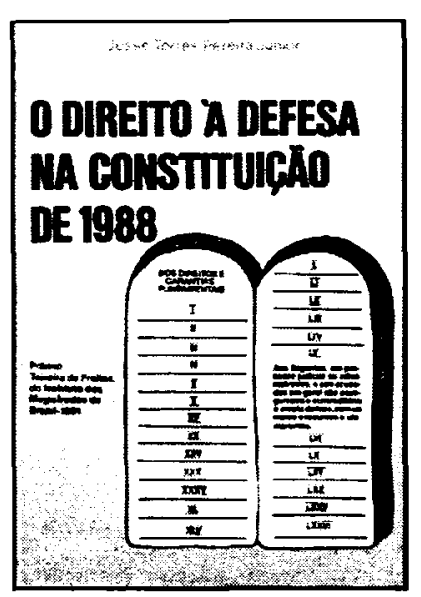

$\mathrm{O}$ art. $5^{\circ}$, LV, da Constituiçāo Federal de 1988, estendeu ao processo administrativo inominado $\mathrm{e}$ aos acusados em geral o direito à defesa e ao contraditório, até então garantias expressamente dirigidas apenas ao processo judicial penal e ao processo administrativo disciplinar. A aplicação do preceptivo constitucional pende de distinguirem-se, entre os numerosos e variados procedimentos que circulam no cotidiano dos órgãos e entidades da administração pública, aqueles que comportam a natureza de processo, e de identificarem-se, nas estruturas da organização social, os "acusados em geral".

Ref. 0032

Form. 14x21

Brochura

1991

182 págs.

\section{O Direito Constitucional e a Efetividade de suas Normas}

Luis Roberto Barroso

Nesta obra, o autor sai a campo em defesa da efetividade da Constituição - cercada de ameaças das mais diversas origens - apontando caminhos, abrindo perspectivas, descobrindo soluçōes. Examina fatos históricos e fenômenos políticos - bases de análise da "frustração constitucional" em nosso país. Em seguida, expōe com minúcia os diferentes mecanismos de efetivação das normas constitucionais, percorrendo todas as ações instituídas pela Carta de 1988, com destaque para o mandado de injunçāo, o controle de inconstitucionalidade por omissão e o mandado de segurança coletivo.

Ref. 0024

Form. 14x21
Brochura

1999
449 págs.

4: ed. 